\title{
Analysis of Factors Influencing Intensity Use of Mobile Banking Islamic Bank
}

\author{
Sutarminingsih ${ }^{1}$, Lukman M Baga ${ }^{2}$, Imam Teguh Saptono ${ }^{3}$ \\ ${ }^{1,3}$ Graduate IPB Business School \\ ${ }^{2}$ Center of Islamic Business and Economic Studies (CIBEST), IPB University, Indonesia. \\ Corresponding Author: Sutarminingsih
}

\begin{abstract}
The development of internet users and technology has influenced the banking industry to transform its services towards digital. XYZ Sharia Bank is one of the banks that implements a digital banking service strategy through mobile banking. The purpose of this study is to describe the characteristics of mobile banking users, then analyze what influences the behavioral intentions of users in increasing the intensity of mobile banking use, and provide recommendations for development strategies for Islamic Bank XYZ to increase the intensity of mobile banking use. The results of this study qualitatively indicate that the characteristics of XYZ Islamic Bank mobile banking users are dominated by millennial generation males. XYZ Syariah Bank is the choice for mobile banking services because of its practical and flexible use. In addition to general banking transactions, $\mathrm{XYZ}$ Syariah Bank mobile banking is also an option because it provides services to complement people's lifestyles, namely for digital wallet refills, online shopping payments through the marketplace/e-commerce. The results of the research quantitatively indicate that all of the variables studied, namely perceived usefulness, ease of use, interaction needs, perceived risk, perceived cost of use, trustworthiness, credibility, and compatibility with lifestyle and needs have a significant influence on the intensity of using Islamic Bank mobile banking XYZ, where the biggest factor in influencing the intensity of the use of XYZ Islamic Bank's mobile banking is compatibility with lifestyle and needs
\end{abstract}

Keywords: Digital Banking, Mobile Banking, Intensity of Using, Sharia Bank

\section{INTRODUCTION}

In line with the development of information technology, the services provided by the Bank are undergoing an evolution that leads to digital banking services.

Mobile banking services can answer the demands of customers who want fast, secure, convenient, cheap, and available service at any time (24 hours non-stop), and can be accessed from anywhere, simply via mobile phone.

Bank Syariah XYZ as one of the major Islamic banks in Indonesia, is also committed to providing the best service to customers by improving digital services. Bank Syariah XYZ mobile banking feature is expected to not only serve to help customers in terms of financial transactions but also nonfinancial. It is expected that the mobile banking application of Bank Syariah XYZ can become a super app for Muslims today because in it there are zakat / waqf payment features, the Qur'an, tracking the location of the nearest mosque, prayer times and hadith and spiritual quotes. In addition, this application can also be used for customer needs with various features including digital payment services.

Although many benefits obtained by customers, but in fact this service is very rarely used by customers and tends not to be in demand. Customers prefer to make transactions via ATM or by queuing at the bank. In fact, the number of mobile banking users in Indonesia is less than internet users. 
Based on the results of the Indonesian Polling Study in collaboration with the Indonesian Internet Service Providers Association (APJII) in 2018, out of a total population of 264 million Indonesians, there were 171.17 million people or about 64.8 percent who were already connected to the internet, while internet users who accessed digital banking services were only $7.39 \%$ or as many as 12.6 million in 2018. According to research by social media management platform HootSuite and social marketing agency We Are Social titled "Global Digital Reports 2020", nearly 64 percent of Indonesians are already connected to the internet network. The research released at the end of January 2020 said that the number of internet users in Indonesia has reached 175.4 million people, while the total population of Indonesia is around 272.1 million.

From the internal data of Bank Syariah XYZ, it is known that as of June 2020, from 6.3 million customers of Bank Syariah XYZ, the penetration of mobile banking usage is $20 \%$ or 1.2 million customers and those who actively make transactions amount to $36 \%$ of total mobile banking users or $7 \%$ of the total number of customers.

In this regard, the intention of mobile banking behavior becomes very important to be studied in this study. The technology acceptance behavior model refers to the Technology Acceptance Model (TAM) developed by Davis et al. (1989). This model uses four main constructs, name perceived usefulness, perceived ease of use, attitude toward behavior or attitude toward using technology (attitude toward using technology), and behavioral intention (Davis 1989).

Therefore, the purpose of this study is to describe the characteristics of mobile banking users of Bank Syariah XYZ, then analyze what affects the intention of user behavior in increasing the intensity of mobile banking use to conduct banking transactions, and recommend the development that Can be done by Bank
Syariah XYZ to increase the intensity of mobile banking use.

The development of information and communication technology in the financial industry has changed the way banks provide services to their consumers (Hoehle et al. 2012).

Mobile banking is one of the interactive distribution channels that allows people to perform banking activities such as checking balances, making payments, credit applications and other banking transactions through mobile devices (Al-Akhras et al. 2011). However, until now the level of mobile banking usage is still lower than expected (Yu 2012). As a result, the use of mobile banking has become a core issue of various studies around the world (Palani and Yasodha 2012).

Koenig-Lewis et al. (2010) states that young people are more likely to use mobile banking because it suits their lifestyle, as is Howcroft et al. Sangle and Awasthi (2011) state that people who have a dense and dynamic life like in big cities use mobile banking more often than people who do not have many activities or settle in the suburbs.

Koenig-Lewis et al. (2010) asserts that the interest in using customers becomes the main barrier that hinders the development of mobile banking. It is unlikely that banks will increase their investment in mobile banking if customers do not see profits in it and if the way of use is not widely socialized (Koenig-Lewis et al. Thus, understanding what is hindering customers from using mobile banking becomes very important (Koenig-Lewis et al. 2010).

Banking apps that allow online access to banking services are the main way in which banks offer mobile banking services (Cruz et al. Suoranta (2003), argues that mobile banking allows its users to check account balances, make transaction history questions, transfer funds, pay bills, trade stocks and manage asset portfolios. Wilcox (2009) also predicts that the reach 
and users of mobile banking services are likely to increase in the future.

Arahita and Hatammimi (2015) argue that the successful performance of a service system should not be based on simple and instant use, but on the intention of continuous reuse. Reuse intention is defined as the level of subjective preference of consumers to use the service again and to recommend this service to family and friends. Before customers use this service, they have special requirements. On the basis of these needs and after tracing the relevant information provided initial experience, the customer filters, evaluates and compares the information/services and then makes a rational decision to re-select the same online service.

The technology acceptance model (TAM) (Davis 1989) is one of the acceptable and widely used models in the field of information technology. This model explains the nature of beliefs-attitudeintention-behavior and its relationship to the level of acceptance of information technology. Mobile banking has become a new business model influenced by many types of factors (Sheng et al. Among various theories and models, many are presented in literature (e.g., Chang et al. (2012); Dimitriadis and Kyrezis (2010); JinBaek et al. (2013); JinBaek and Sungmin (2012); Susanto et al. (2012); Zhenhua et al. (2009) use TAM or one different variation to investigate the use of mobile banking worldwide.

Based on the TAM (Davis 1989) model and developed by Hanafizadeh (2014), given are factors that affect the intensity of mobile banking use, namely:

1. Perceived Usefulness is defined as the subjective probability that using technology will improve an individual's performance (Davis et al. 1989).

2. Perceived ease of use is defined as the user's willingness to use the system (Davis et al. 1989).

3. Need for personal interaction is defined as a private exchange between a client and a bank officer (Wessels and Drennan 2010).

4. Perceived risk is defined as consumers' consideration of potential risks in their adoption decisions, such as personal data or identity theft during online transactions (Sheng et al. 2011).

5. The perception of use (perceived cost of use) is defined as financial considerations prior to adopting mobile banking services, including handset fees, subscriptions, services and communication fees, which may affect consumer intentions to use the services (Wang et al. 2003).

6. Trust is defined as the intention of trust that makes a person feel safe enough to be willing to rely on a trustee (Lee and Chung 2009).

7. Credibility is defined as the personal belief that consumers have the technology to securely conduct transactions by maintaining the privacy of personal information (Daud et al. 2011)

8. Compatibility with lifestyle and needs is defined as the extent to which mobile banking services are in line with consumers' lifestyles and current needs (Kleijnen et al. 2004; Wu and Wang 2005).

\section{METHOD}

The type of data used in this study consists of primary data and secondary data. Primary data is obtained from the spread of online surveys through google form to be able to reach a wider range of respondents in Indonesia. Secondary data obtained from literature studies (journals, books, the internet, and other literature) related to the matters discussed in this study for use in helping answer research questions and hypotheses, as well as to understand primary data in more depth.

Based on this research, the data collection and data analysis conducted is qualitative research with descriptive analysis and quantitative research with Structural Equation Model SEM analysis. 
Qualitative research with descriptive analysis is used to describe identifying respondent characteristics and identifying respondents' behavior in using mobile banking.

Quantitative research with SEM analysis is used to analyze what factors affect the intensity of mobile banking use of Bank Syariah XYZ. The population in this study is customers of Bank Syariah XYZ throughout Indonesia who have used mobile banking services. The sampling technique used in this study is nonprobability sampling. The type of sampling in the nonprobability sampling technique chosen is purposive sampling. Malhotra (2014) recommends the number of samples that must be met for SEM estimate is 5 times the parameter to be estimated, then with 31 variables observed the minimum required 155 respondents. In this study the number of samples studied was as many as 200 respondents so that it met the minimum number of samples needed. The variable approach is used with reference to the TAM by model (Davis et al. (1989) and Hanafizadeh (2014). In general, the image of the intensity model of the use of mobile banking Bank Syariah XYZ developed by researchers.

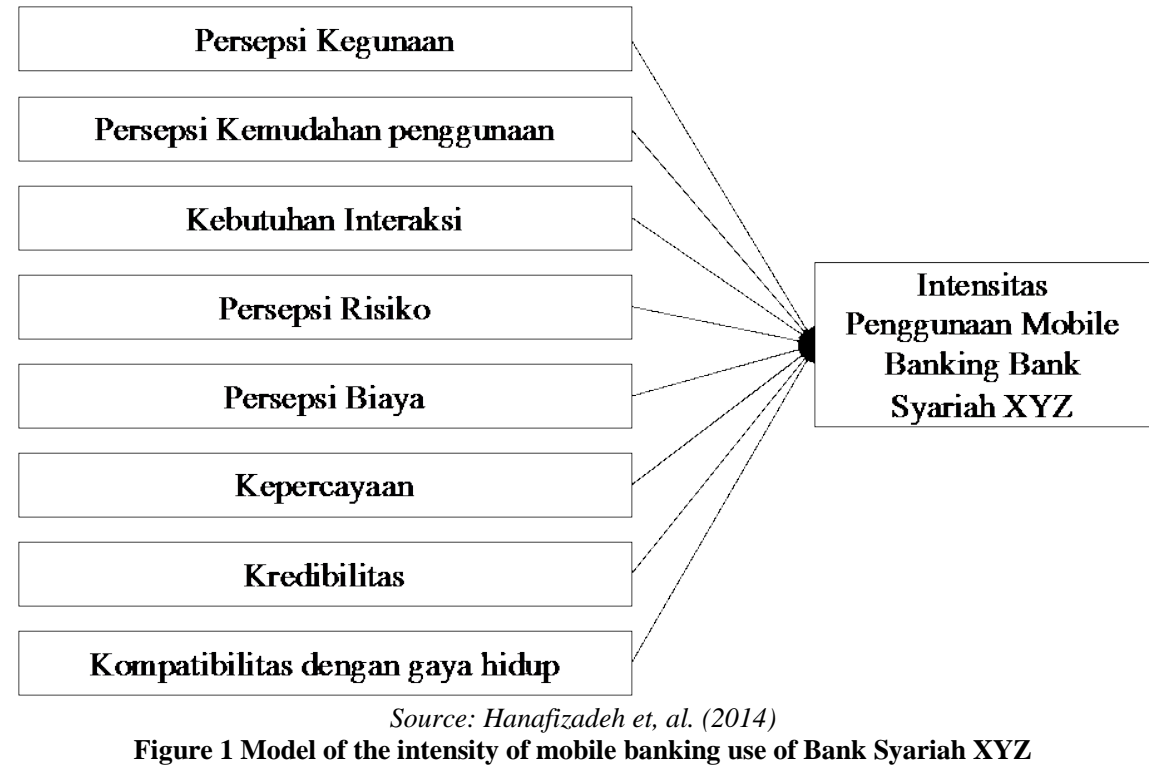

Based on figure 1, it can be explained that:

1. H0: It is suspected that there is no influence between usability perception variables (X1), ease of use (X2), interaction needs (X3), risk perception (X4), cost of use perception (X5), trust (X6), credibility (X7), and compatibility with lifestyle and needs (X8) with the intensity of use (Y) of mobile banking of Sharia Bank XYZ

2. H1: It is suspected that there is an influence between the usability perception variable (X1) and the intensity of use (Y) of mobile banking of Bank Syariah XYZ

3. H2: It is suspected that there is an influence between the ease of use variable (X2), with the intensity of mobile banking use of Bank Syariah XYZ (Y)

4. H3: It is suspected that there is an influence between the interaction needs variable (X3) and the intensity of use (Y) of mobile banking of Bank Syariah $\mathrm{XYZ}$

5. H4: It is suspected that there is an influence between the risk perception variable (X4) and the intensity of use (Y) of mobile banking of Bank Syariah $\mathrm{XYZ}$

6. H5: It is suspected that there is an influence between the variable perception of cost of use (X5), with the intensity of use $(\mathrm{Y})$ of mobile banking of Bank Syariah XYZ 
7. H6: It is suspected that there is an influence between the trust variable (X6) and the intensity of use (Y) of mobile banking of Bank Syariah XYZ

8. H7: It is suspected that there is an influence between the credibility variable (X7) and the intensity of use (Y) of mobile banking of Bank Syariah $\mathrm{XYZ}$

9. H8: It is suspected that there is an influence between the compatibility variable with lifestyle and needs (X8) with the intensity of use $(Y)$ of mobile banking of Bank Syariah XYZ

\section{RESULT}

Based on the characteristics of respondents of mobile banking users of Bank Syariah XYZ can be submitted the results of the following research:

1. Based on research data submitted that as many as 138 (71\%) respondents have a bank rekening other than Bank Syariah XYZ, 135 (68\%) respondents make >10 transactions in a month, and as many as 178 (92\%) respondents have used mobile banking Bank Syariah XYZ for $>1$ year.

2. Respondents to mobile banking users of Bank Syariah XYZ chose mobile banking is because of its practical and flexible use (43.8\%), then the next reason is the transaction facilities owned (28.4\%) and can be used at any time (17.5\%).

3. The most widely made transactions on bank Syariah XYZ mobile banking are transfer /transfer transactions (96.4\%), followed by balance checking transactions (91.8\%) and purchases of HP vouchers, PLN Prepaid, and data packages (84.5\%). While the fewest transactions are open an account (14\%) and block the card (10\%).

4. From the respondent data it is known that mobile banking users of Bank Syariah XYZ have digital wallets Ovo (67\%), Gopay (61\%) and e-money (53\%). While e-commerce that is often used for online shopping is Shopee (62),
Tokopedia (46\%) and Bukalapak (28\%). This is in accordance with the digital wallet top up service and e-commerce payments owned by mobile banking Bank Syariah XYZ. However, there are $35.6 \%$ of shopee pay users who do not have a top-up service in mobile banking Bank Syariah XYZ.

5. Respondents to mobile banking users of Bank Syariah XYZ most (99\%) know and consider the importance of Islamic service content. The most important types of Islamic content/services are the prayer schedule (38\%) and qibla directions (25\%).

6. Mobile banking users of Bank Syariah XYZ also make ZISWAF (Zakat, Infaq, Shodaqoh, Waqf) payments through mobile banking (90\%).

7. Sumber information media that has an important role in the dissemination of information mobile banking services Bank Syariah XYZ is through customer service (76\%), friends / co-workers / family (50\%) and social media Instagram (33\%).

The data analysis in this study used linear structural relationship (LISREL) program software. The first step is the analysis of the measurement model. The measurement model match test in SEM uses validity and reliability tests. The results of the validity test per dimension on each factor changer are described in detail using standardized loading factor (SLF) criteria. Ramadiani (2010) explains that to obtain the meaning of the dimensions extracted in forming latent variables, it can be obtained from the SLF value of each dimension. If an SLF value greater than 0.50 is obtained, it indicates that the dimension is good enough to be extracted to form a latent variable.

Ramadiani (2010) also explained that the validity test of the measurement model can be checked by looking at the values of $t$-values $\geq 1.96$ and $\mathrm{SLF} \geq 0,50$ of the variables observed in the model. As for testing reliability according to Hair et al. (2014), can use construct reliability (CR) 
and variance extracted (VE). A measurement is said to have high reliability when $C R$ values $\geq 0,7$ and $\mathrm{VE} \geq 0,5$

Based on the measurement model tests carried out on each variable in the research model, it is conveyed that the validity and reliability for all indicators on each latent variable is good. This is because each indicator qualifies the validity indicator with an SLF value of $\geq 0,50$ and a $\mathrm{t}$-value $\geq 1,96$

Based on the results of structural models to answer the research hypothesis, it can be delivered the output of structural models consisting of $t$ calculation and SLF. Figure t calculate structural model Factors Factors That Affect the Intensity of Mobile Banking Use of Bank Syariah XYZ can be seen in Figure 2, while the SLF image of the structural model of Factors Affecting the Intensity of Mobile Banking Use of Bank Syariah XYZ can be seen in Figure 3 as follows:

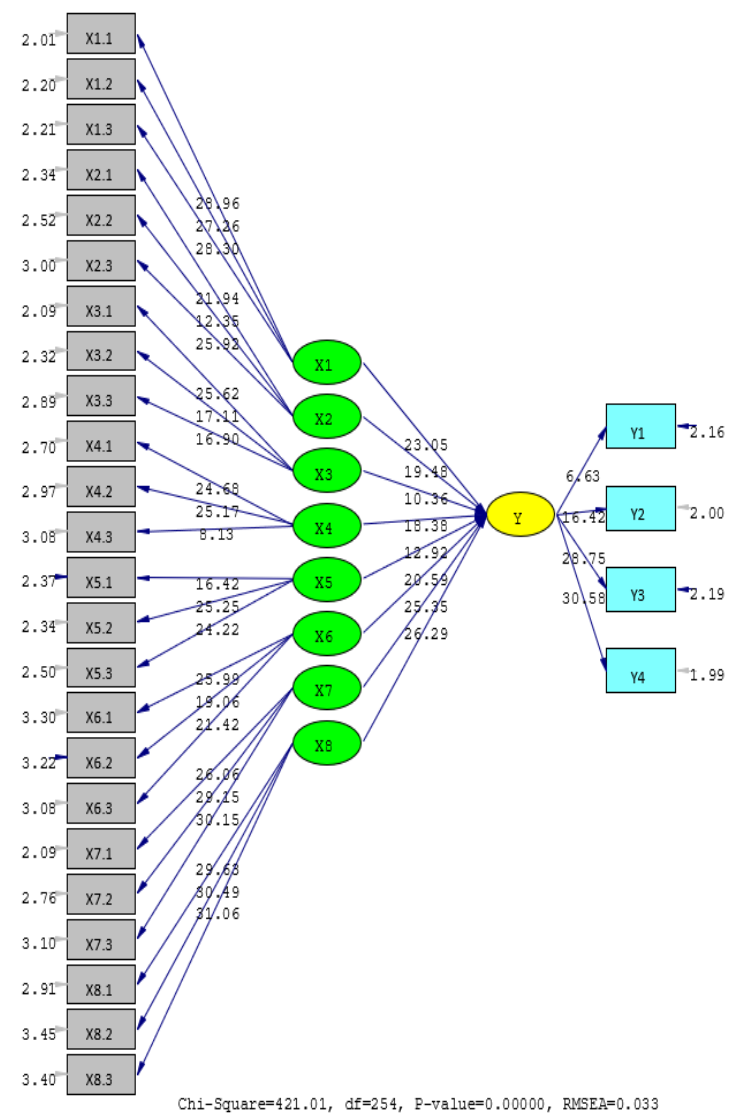

Figure 2 Results of structural model t-values Source: Lisrel (2021)

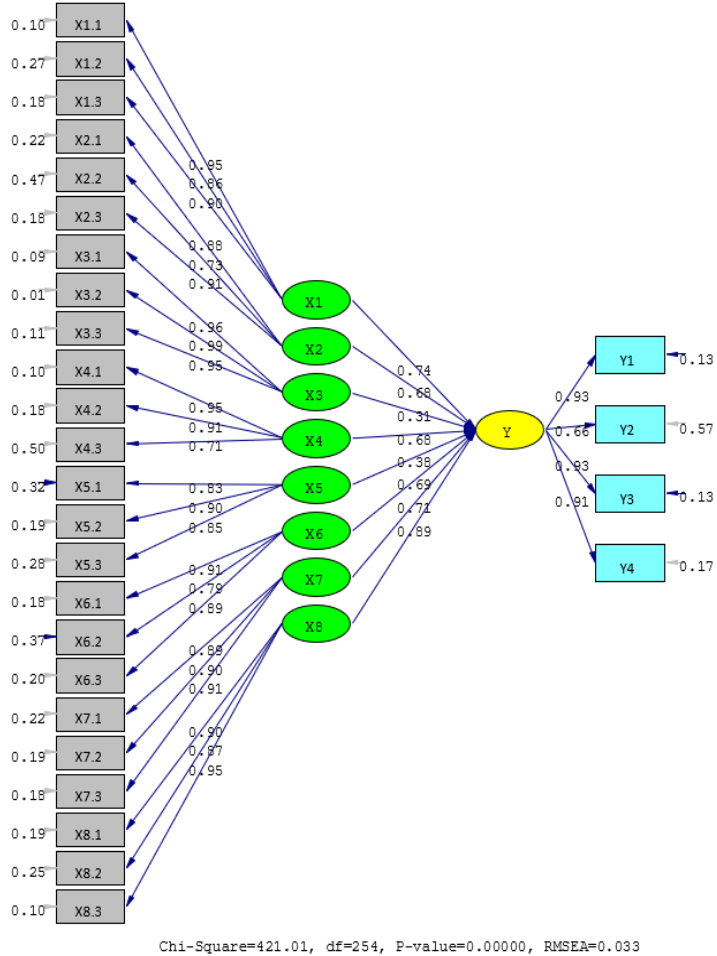

Figure 3 Standardized loading factor (SLF) structural model Source: Lisrel (2021)

It can be conveyed that each variable, namely usability perception, ease of use, interaction needs, risk perception, cost of use perception, trust, credibility, and compatibility with lifestyle and needs has a significant influence on the intensity of use variables.

The most influential factor in increasing the intensity of the use of mobile banking Bank Syariah XYZ is compatibility with lifestyle and needs, with an SLF value of 0.89 . While the least influential factor in increasing the intensity of the use of mobile banking Bank Syariah XYZ is the need for interaction, with an SLF value of 0.31.

\section{CONCLUSION}

Based on the results of the research conducted, the conclusions obtained from this study are:

1. The characteristics of mobile banking users of Bank Syariah XYZ are mostly young millennials who have been actively using mobile banking for more than 1 year. The main consideration of respondents in using mobile banking Bank Syariah XYZ is due to its practical 
and flexible use. The types of transactions that are often carried out on mobile banking Bank Syariah XYZ in addition to general banking transactions such as transfers, transfer and balance checking are bill payment transactions, online shopping and e-wallet top-ups. Islamic service content such as prayer schedules and qibla directions are considered important in mobile banking Bank Syariah XYZ. ZISWAF payments (Zakat, Infaq, Shodaqoh, Waqf) are also one of the many transactions made on mobile banking bank Syariah XYZ.

2. The overall variables studied, namely usability perception (X1), ease of use (X2), interaction needs (X3), risk perception (X4), cost of use perception (X5), trust (X6), credibility (X7), and compatibility with lifestyle and needs (X8) had a significant influence on the intensity of use $(\mathrm{Y})$ of mobile banking of Bank Syariah XYZ. The biggest factor in influencing the intensity of mobile banking use of Bank Syariah $\mathrm{XYZ}$. It is compatibility with lifestyle and needs. This shows that mobile banking users strongly consider lifestyle conformity factors that include compatibility with today's lifestyle, how to perform banking activities, and are compatible with most banking activities.

3. Development recommendations that can be made by Bank Syariah XYZ in increasing the intensity of mobile banking use are the development of features that accommodate more participation from young customers as today's customers such as digital wallets and marketplace / e-commerce payments, the development of Islamic service content as one of the advantages of mobile banking Bank Syariah XYZ as well as being a differentiator with other bank mobile banking services, socialization of mobile banking features in addition to financial transaction services, as well as social transaction services (ZISWAF) and spiritual services (prayer schedules, qibla directions, Quran), increased awareness of online account opening features that have existed today through mobile banking but not widely known and disturbed.

\section{Acknowledgement: None}

\section{Conflict of Interest: None}

\section{Source of Funding: None}

\section{REFERENCES}

1. Al-Akhras MT, Al-Sayyed R, Alian M, Qwasmi D. 2011. Innovative secure mobile banking services. International Journal of Interactive Mobile Technologies (IJIM), 5(1), 12-22. doi:10.3991/ijim.v5i1.1516

2. [APJII]. 2018. Penetration and Profile of Indonesian Internet User Behavior. [internet]. [[accessed in 2020 June 18]]. Available on: https://apjii.or.id/content/read/39/410/HasilSurvei-Penetrasi-dan-Perilaku- UserInternet-Indonesia-2018

3. Arahita CL, Hatammimi J. 2015. Factors Affecting the Intention to Reuse Mobile Banking Service. International Journal of Research in Business and Social Science (2147- 4478), 4(4), 15-23. doi: 10.20525/ijrbs.v4i4.15

4. Chang CC, Yan CF, Tseng JS. 2012. Perceived convenience in an extended technology acceptance model: Mobile technology and English learning for college students. Australasian Journal of Educational Technology, 28(5). doi:10.14742/ajet.818

5. Cruz P, Neto LBF, Muñoz-Gallego $P$, Laukkanen T. 2010. Mobile banking rollout in emerging markets: evidence from Brazil. International Journal of Bank Marketing,28(5), 342-371. doi:10.1108/02652321011064881

6. Davis FD. 1989. Perceived usefulness, perceived ease of use, and user acceptance of information technology. MS Quarterly (online), Vol. 13 Iss. 3, pg. 10:2307/249008

7. Daud NM, Ezalin N, Kassim M, W Series, Wan R, Said M, Noor MM. 2011. Determining critical success factors of mobile banking adoption in Malaysia. Journal of Applied Sciences Research, 7(9), 252-265. 
8. Dimitriadis S, Kyrezis N. 2010. Linking trust to use intention for technology-enabled bank channels: The role of trusting intentions. Psychology \& Marketing, 27(8), 799-820. doi:10.1002/mar.20358

9. Hair Jr JF, Black WC, Babin BJ, Anderson RE. 2010. Multivariate Data Analysis. A Global Perspective. 7th Edition. New York (USA): Pearson Education, Upper Saddle River.

10. Hanafizadeh P, Behboudi M, Koshksaray AA, Tabar MJS. 2014. Mobile-banking adoption by Iranian bank clients. Telematics and Informatics, 31(1), 62-78.

11. Hoehle H, Scornavacca E, Huff S. 2012. Three decades of research on consumer adoption and utilization of electronic banking channels: A literature analysis. Decision Support Systems, 54(1), 122-132. doi:10.1016/j.dss.2012.04.010.

12. Howcroft B, Hamilton R, Hewer P. 2002. Consumer attitude and the usage and adoption of home-based banking in the United Kingdom. International Journal of Bank Marketing,20, 111-121.

13. JinBaek K, Sungmin K. 2012. A study on the factors affecting the intention to use smartphone banking: The Differences between the transactions of account check and account transfer. International Journal of Multimedia \& Ubiquitous Engineering. 7(3): 87-96.

14. JinBaek K, Sungmin K, Hoon SC. 2013. Smartphone banking: The factors influencing the intention to use. KSII Transactions On Internet \& Information Systems,7(5), $\quad 1213-\quad 1235$. doi:10.3837/tiis.2013.05.016

15. Kleijnen M, de Ruyter K, Wetzels M. 2004. Consumer adoption of wireless services: discovering the rules, while playing the game. Journal of Interactive Marketing. 18 (2): 51-61.

16. Koenig-Lewis N, Palmer A, Moll A. 2010. Predicting young consumers' take up of mobile banking services. The international Journal of Bank Marketing, 28(5), 410-432. doi:10.1108/02652321011064917

17. Kotler P, Kartajaya H, Setiawan I. 2019. Marketing 4.0 Moves from Traditional toDigital. Jakarta (ID): PT Gramedia Pustaka Utama.

18. Lee KC, Chung N. 2009. Understanding factors affecting trust in and satisfaction with mobile banking in Korea: A modified
DeLone and McLean's model perspective. Interacting with Computers. 21(5-6): 385392.

19. Malhotra NK. 2004. Marketing Research: An Applied Orientation, 4th Ed. London(UK): Prentice-Hall International.

20. Palani A, Yasodha P. 2012. A study on customer perception towards mobile banking in Indian overseas bank Chennai. International Journal of Marketing and Technology. 2(4): 262-277.

21. Ramadiani. Structural equation model for multivariate analysis using LISREL. Journal of Informatics Mulawarman. 5(1): 14-18

22. Sangle PS, Awasthi P. 2011. Consumers expectations from mobile CRM services: a banking context. Business Process Management Journal, vol. 17 no. 6, pp.898918.

23. Sheng M, Wang L, Yu Y. 2011. An empirical model of individual mobile banking acceptance in China. International Conference on Computational and Information Sciences, 434-437. doi:10.1109/Iccis.2011.75

24. Suoranta M. 2003. Adoption of mobile banking in Finland, Jyva Skyla Studies in Business and Economics. [thesis]. Skyla (FD): University of Jyva Skyla

25. Susanto A, Chang Y, Zo H, Park MC. 2012. The role of trust and security in Smartphone banking continuance. 2012 IEEE International Conference on Systems, Man, and Cybernetics (SMC), 2133-2138. doi:10.1109/Icsmc.2012.6378055

26. Wang YS, Wang YM, Lin HH, Tang TI, 2003. Determinants of user acceptance of internet banking: An empirical study. International Journal of Service Industry Management (online journal from Proquest), Vol.14, Iss.5, pg. 501.

27. We Are Social, Hootsuite. 2020. Digital Data Indonesia 2020. [internet]. [accessed June 18, 2020]. Available from: https://datareportal.com/reports/digital2020-indonesia

28. Wessels L, Drennan J. 2010. An investigation of consumer acceptance of $\mathrm{M}$ banking. International Journal of Bank Marketing,28(7), 547568.doi:10.1108/02652321011085194

29. Wilcox H. 2009, Banking on the mobile, white paper, Juniper Research, Basingstoke, www.juniperresearch.com. 
30. Wu JH, Wang SC. 2005. What Drives Mobile Commerce? An Empirical Evaluation of the Revised Technology Acceptance Model. Information Management. 42(2005): 719-729.

31. Yu C. 2012. Factors affecting individuals to adopt mobile banking: Empirical evidence from the UTAUT model. Journal of Electronic Commerce Research. 13(2): 104121.
32. Zhenhua L, Qingfei M, Shaobo J. 2009. An empirical study on mobile banking adoption: The Role of trust. Electronic Commerce and Security. 5(4): 7-13.

How to cite this article: Sutarminingsih, Baga LM, Saptono IT. Analysis of factors influencing intensity use of mobile Banking Islamic Bank. International Journal of Research and Review. 2021; 8(11): 441-449. DOI: https://doi.org/10. 52403/ijrr.20211156 